\title{
Preservations, packaging materials and temperatures affected on quality changes of ready-to-eat bamboo shoot during storage
}

\author{
Ratchanee Charoen ${ }^{1,}$, Plengsuree Thiengnoi ${ }^{2}$, Regine Schoenlechner ${ }^{3}$ and Sutee Wangtueai ${ }^{4}$ \\ ${ }^{1}$ Faculty of Agro-Industry, King Mongkut's University of Technology North Bangkok, Muang, Prachinburi 25230, Thailand. \\ ${ }^{2}$ Academic and Curriculum unit, Mahidol University, Nakhonsawan campus, Nakhonsawan 60130, Thailand. \\ ${ }^{3}$ Department of Food Science and Technology, University of Natural Resources and Life Sciences, Vienna, 1180, Austria. \\ ${ }^{4}$ College of Maritime Studies and Management, Chiang Mai University, Samut Sakhon 74000, Thailand.
}

\begin{abstract}
The influences of preservatives types (sodium benzoate and citric acid), storage temperatures (10, 4 and 25 degrees Celsius) and container types (low-density polyethylene; LDPE and laminate nylon) on quality changes (physical, microbiological and sensory) of ready-to-eat trimmed and sliced bamboo shoot (slice shape) during storage were investigated. The ready-to-eat bamboo shoot treated with citric acid had good color and microbial stabilities than the control (without the preservatives) and the treated with sodium benzoate at 4th week of storage period. However, the weight loss percentage of the sodium benzoate treatment was lower than the citric acid treatment and the control. At 4 degrees Celsius of storage temperature, the bamboo shoot had the lowest of weight loss percentage compared to other treatments, which the qualities of bamboo shoot at 14 days of storage in this temperature showed an acceptable of weight loss, color, microbial and sensory qualities and could be stored up to 21 days before spoilage. While the storage at 25 degrees Celsius, the bamboo shoot had a shelf life for 7 days. The storage of bamboo shoot in 60 micron LDPE bag was comparable to the laminate nylon bag in term of all quality aspects.
\end{abstract}

Keyword. Bamboo shoot, Fresh cut, Ready-to-eat, Preservative

\section{Introduction}

Bamboo is a very useful plant. The traditional wicker is one of bamboo benefit in the past to present. Bamboo is more valuable. It is used in cosmetics, fabric industry, renewable energy such as biodiesel and bio gas, and activated charcoal production. In the present, Young bamboo shoots are used as a common food material in many countries like China, Japan, Philippines, India, US, Nepal, Bhutan, Korea, Australia, New Zealand, Malaysia, Indonesia, and Thailand [1-2] which the commercially major export countries are China, Taiwan, and Thailand [3].

In Thailand, bamboo shoot production is about 300,518 tonnes a year with 67,800 hectare of producing area [2]. Recently, one of important cultivation area is Prachinburi province as Prachantakham, Amphoe Muang, and Nadi district, which produces a bamboo shoots namely Pai-tong )Dendrocalamus asper(. The plantation areas and yield are approximately 8,600 hectare and 16 tonnes per hectare [2, 4]. Thus, the bamboo shoot is not only economy crop, but also it is one of reputation product of Prachinburi province, especially during August to September. In during the season, the amount of fresh Pai-tong bamboo shoot is over demand for fresh consumption and the price dramatically decline to about $0.2-0.5 \quad$ USD $/ \mathrm{kg}$. To solvent this problem, the bamboo shoot has been produced to variety products such as dried, fermented, canned bamboo shoot, and boiled bamboo shoot in bucket [5-6]. Most of the consumption of bamboo shoots in season is consumed as fresh while bamboo shoots consumed as dried, fermented or pickled style for offseason. Fresh bamboo shoots are produced by chopping inner soft portion of shoots into thin slices after peeling off and treating them in water for 2-3 hours. Another fresh bamboo species is boiled for 1 hour and shocked in water to remove bitterness of shoot and able to keep until consumed for 2 day and 5-7 day in the fridge. For the shelf stable, fresh bamboo are available for limited period and have a short shelf life. Therefore, it must be processed and used immediately after harvesting [7-8].

Generally, the storage temperature, time, preprocessing methods and packaging influence the shelf life of fresh bamboo shoot, which the deterioration is characterized by unusual increase in color, firmness and stiffness, and fungal infection in the edible parts of shoots $[1,9]$. In present, the market of the processed bamboo shoots accounts in a large proportion, while consumer prefer a fresh bamboo shoots because it has much better taste and higher nutrition. In addition, the various factors during postharvest handling was affected

* Corresponding author: ratchanee.c@agro.kmutnb.ac.th 
the shoots qualities leading to the subsequent rapid deterioration $[1,3]$.

In Thailand, the bamboo shoot harvesting is done at early morning and transported to preprocessing plant for trimming, peeling, packing, and transporting to wholesale market. Some chemicals such as sulfur dioxide $) \mathrm{SO}_{2}$ ( are treated in the whole peeled bamboo shoot for marketing reason. After peeling, the whole shoots are soaked in the $10-30 \%) \mathrm{w} / \mathrm{v}\left(\mathrm{SO}_{2}\right.$ solution for 3- 5 second and then packed into polypropylene bags about $10 \mathrm{~kg} / \mathrm{bag}$ [5, 9-10]. Other preservatives sodium benzoate citric acid, the food additives that are generally recognized as safe by the Food and Drug Administration. Both preservatives are highly effective in food and commonly used in the food industry. In addition, these additives are economically and the possibility of production costs [7, 10]. The comparison of the packaging type is challenging. Packaging material, thickness and permeability properties of the packaging influence the decision on the selection of suitable package for consumer distribution. LDPD plastic type is safe for food, more transparent while Laminate/nylon plastic is stiffer and more opaque, including the strengths of this package is a good barrier to oxygen and water permeability $[3,8,10]$.

Therefore, the processed bamboo shoot is not only one of the many approaches to increase the value of the products expanding marketing channels but also the consumers could easily use for cooking when it had cutting and trimming into appropriated shapes and sizes [11]. According to previous reports, bamboo shoot required some heat treatments, for example, blanching for at least $3 \mathrm{~min}$ in order to prevent discoloration of the fresh bamboo shoot. Due to the heating cloud be used for inactivation of related enzymes )such as polyphenol oxidase, peroxidase, and phenylalanine ammonialyase(, preventing pigment instabilities and browning reactions during storage [12-15]. The heat treatment could be a potential tool to decrease disease incidence, respiration and ethylene production rate and lead to a consistent with the reduction in shoot firmness during storage at $20^{\circ} \mathrm{C} \mathrm{[15].} \mathrm{Moreover,} \mathrm{the} \mathrm{storage} \mathrm{conditions} \mathrm{and} \mathrm{the} \mathrm{food}$ additive using have been reported to prevent a spoilage of bamboo shoots for example sodium nitroprusside treatment [16], salicylic acid treatment [17], 1methylcyclopropene )1-MCP( treating [18]. The effect of packaging and storage temperature to fresh bamboo shoots were studied [3] and the coating of bamboo shoot with antimicrobial and enzymatic antibrowning film resulted in lower weight loss, color changes and reduction in surface microbial count [19]. As a guideline, this study aimed to improve the overall quality of readyto-eat bamboo shoot products, which is common trade barrier. The combination effect of preservatives, storage temperatures, and container materials on some physicochemical, microbiological quality, and the preference of ready-to-eat bamboo shoots were investigated during 1 month storage.

\section{Materials and Methods}

\subsection{Preparation of bamboo shoot}

Fresh Pai-tong bamboo shoots )Dendrocalamus asper( were locally purchased from farmers in Noen Hom district, Prachinburi, Thailand during August-October. The bamboo shoots were kept at $4 \pm 1^{\circ} \mathrm{C}$ until use )no longer than three days(. Fresh bamboo shoots were washed to remove other residuals, and peeled the skin off. The peeled bamboo shoots were then trimmed and sliced with $3.0 \mathrm{~mm}$ thickness using slicer machine )Savioli, Food EQ Co., LTD, Thailand(. The sliced bamboo shoot was blanched by using boiling water ) $95 \pm 5^{\circ} \mathrm{C}$ ( for $10 \mathrm{~min}$, cooled down in cold water ) $4 \pm 1^{\circ} \mathrm{C}$ (, and drained in plastic basket for $5 \mathrm{~min}$. Food grade of sodium benzoate and citric acid was obtained from Amata food \& Chemical, CO., LTD, Thailand. The low-density polyethylene $) \operatorname{LDPE}(\quad) 60 \mu \mathrm{m}$ of thickness( and laminate/nylon bags ) $80 \mu \mathrm{m}$ of thickness( were purchased from T.S.T Plaspack Co., Ltd, Thailand and Qingdao RTGYH Packaging Co., LTD, China, respectively.

\subsection{Chemical treatments, packaging, and storage conditions}

Pretreated bamboo shoots as described in the previous section were treated with and without food preservatives such as citric acid ) $0.1 \% \mathrm{w} / \mathrm{v}$ ( and sodium benzoate ) $1.0 \% \mathrm{w} / \mathrm{v}$ ( by soaking for $10 \mathrm{~min}$ and drained in plastic basket for $1 \mathrm{~min}$. The pretreated bamboo shoots ) $110 \pm 7.8 \mathrm{~g} / \mathrm{bag}$ ( were transferred into commercial lowdensity polyethylene )LDPE( bags )60 $\mu \mathrm{m}$ of thickness(, and laminate/nylon bags. Then, the products were stored at shelf storage temperature $) 25 \pm 2^{\circ} \mathrm{C}$ (, cold storage temperature $) 4 \pm 2^{\circ} \mathrm{C}($, and freezer temperature $)-10 \pm 2^{\circ} \mathrm{C}($ for 30 days. Changes in weight loss, color $) \mathrm{L}^{*}$ and $\mathrm{b}^{*}($, microbiological, and sensory of the products were investigated.

\subsection{Physical determination}

\subsubsection{Weight loss}

Weight loss was determined using the method of Badwaik et al [19]. The weight loss during the storage was performed as the percentage of the initial fresh shoot weight remaining after storage. The weight of water condensed in packages was calculated as the difference between fresh weight loss of bamboo shoots and weight loss from packages.

\subsubsection{Color measurement}

The surface color of bamboo shoot slide was carried out using a Minolta model CM-3500d )Minolta, Osaka, Japan(. Five measurement were taken for each treatment. Colors were expressed as CIELAB coordinates. The $\mathrm{L}^{*}$ represents the color lightness on a $0-100$ points scale from black to white and $b^{*}$ is the position between yellow $)+($ and blue $)-($. 


\subsection{Microbiological analysis}

Total plate count )CFU/g( and coliform bacteria )MPN/g( were investigated according to FDA-Bam 2001(. Briefly, the $50 \mathrm{~g}$ of bamboo shoot sample was blended with $450 \mathrm{ml}$ of $0.85 \%$ sterilized normal saline using a stomacher. From this dilution, additional 10-fold dilutions were prepared with sterile normal saline. Pourplate method using plate count agar )PCA( media )Merck, Germany( was used for total plate counts. Most probable number )MPN( method was used for coliform bacteria determination. The inoculated plates and tubes were incubated at $35 \pm 1^{\circ} \mathrm{C}$ for $48 \pm 2 \mathrm{~h}$. All analyses were performed in triplicate.

\subsection{Sensory evaluation}

The preference test in terms of odor and color was performed by 30 untrained panelists. Bamboo shoot samples were packed into plastic tray covered with wrap film and subjected to panelists for evaluation. The 7-hedonic scale was used that included $1=$ dislike extremely, $2=$ dislike very much, $3=$ dislike moderately, $4=$ neither like nor dislike, $5=$ like moderately, $6=$ like very much, and $7=$ like extremely [20].

\subsection{Statistical analysis}

The means and standard variation ) $\mathrm{SD}$ ( of weight loss and color changes were calculated from 3 and 5 replicates, respectively. For experimental design in physical properties, a $2 \times 3 \times 2$ factorial completely randomized design $) \mathrm{CRD}($ was performed. A $2 \times 3 \times 2$ randomized complete block design ) RCBD( was carried out for sensory evaluation. The analysis of variance )ANOVA( was computed at $95 \%$ confident intervals for the population means.

\section{Results and discussions}

\subsection{Physiochemical changes of the ready-to-eat bamboo shoot product}

The processed bamboo shoots treated with different preservatives and container materials were kept at different storage temperatures for 1 month. The bamboo shoots were evaluated for changes in weight loss, color and microbes.

\subsubsection{Changes in weight loss}

As shown in Table 1, without adding any preservatives as the control sample, the samples exhibited increases in the averaged weight loss during the storage from 1 to 4 weeks. It was noted that the weight loss was dramatically increased from the $1^{\text {st }}$ to $2^{\text {nd }}$ week, and the trend was slowed down after the $3^{\text {rd }}$ and $4^{\text {th }}$ week in all treatments. After 4 weeks of the storage, the bamboo shoot stored at $-10{ }^{\circ} \mathrm{C}$ in both LDPE and laminate/nylon bags exhibited the highest weight loss; however, the bamboo shoots stored at $4{ }^{\circ} \mathrm{C}$ in both types of bags showed the lowest weight loss. It should be noted that the bamboo shoots stored at $25^{\circ} \mathrm{C}$ could not be investigated since they were spoiled after the $3^{\text {rd }}$ week of the storage.

For the bamboo shoots treated with citric acid and sodium benzoate, results exhibited that after storage at $-10^{\circ} \mathrm{C}$ for 4 weeks, the bamboo shoots treated with citric acid and sodium benzoate had the highest total weight loss of the products. Results suggested that the storage temperature at 4 ${ }^{\circ} \mathrm{C}$ was considered as the best condition to maintain water release from the product in comparison with other storage temperatures. Nevertheless, the study on the effect of LDPE and laminate/nylon bags on the weight loss of the products at the same temperature revealed that using different container materials did not exhibit significant differences in weight loss. From statistical analysis, preservatives and storage temperatures were significantly influenced on the weight loss of the products $) \mathrm{P}<0.05$ (. In addition, the maturity of sliced bamboo shoots affecting the initial moisture content of the bamboo shoots in the range of $83.6-92.5 \%$ so the weight loss was highly variable.

Kleinhenz and et al. [3] reported the effect of storage temperatures $\left(1,2,8,11,20\right.$ and $\left.25^{\circ} \mathrm{C}\right)$ and container types (heat-sealed PVC, LDPE, LDPE film, micro-perforated LDPE and macro-perforated LDPE) on the total weight loss of the whole bamboo shoot. Results indicated that the bamboo shoot stored in the macro-perforated LDPE bag at high temperatures exhibited higher rate of the weight loss than other conditions. When considering at $5 \%$ weight loss as the critical value, the shelf life of the bamboo shoots stored at $1,8,11$, and $25^{\circ} \mathrm{C}$ was $17,10,5$ and 1 days, respectively. In addition, the weight loss of the bamboo also related to moisture content and humidity of the products. Overall results suggested that the bamboo shoots stored in macroperforated LDPE exhibited superior ability to prevent the weight loss than other bag types. Macro-perforated LDPE could prolong the shelf life of the product up to 4 weeks in comparison with LDPE (21 days) and heat-sealed PVC (14 days).

Table 1. The percentage of weight loss of bamboo shoots with and without preservatives a. control; b. citric acid $(0.1 \% \mathrm{w} / \mathrm{v})$; c. sodium benzoate $(1.0 \% \mathrm{w} / \mathrm{v})$ in different container materials and storage temperatures.

\begin{tabular}{lccccccc}
\hline Sample & \multirow{2}{*}{$\begin{array}{c}\text { Storage } \\
\text { Time (week) }\end{array}$} & \multicolumn{2}{c}{$-10^{\circ} \mathrm{C}$} & \multicolumn{2}{c}{$4^{\circ} \mathrm{C}$} & \multicolumn{2}{c}{$25^{\circ} \mathrm{C}$} \\
\cline { 3 - 8 } & & LDPE & Laminate & LDPE & Laminate & LDPE & Laminate \\
\hline a. Control & 1 & $26.0 \pm 3.1^{\mathrm{a}}$ & $25.0 \pm 4.3^{\mathrm{a}}$ & $17.0 \pm 4.8^{\mathrm{c}}$ & $12.7 \pm 3.8^{\mathrm{d}}$ & $26.0 \pm 3.8^{\mathrm{a}}$ & $20.7 \pm 3.1^{\mathrm{b}}$ \\
& 2 & $42.0 \pm 3.1^{\mathrm{a}}$ & $30.0 \pm 2.8^{\mathrm{b}}$ & $18.0 \pm 4.1^{\mathrm{d}}$ & $20.3 \pm 2.2^{\mathrm{d}}$ & $34.0 \pm 4.7^{\mathrm{ab}}$ & $26.4 \pm 4.2^{\mathrm{c}}$ \\
& 3 & $32.0 \pm 4.5^{\mathrm{a}}$ & $30.0 \pm 3.0^{\mathrm{a}}$ & $21.0 \pm 2.6^{\mathrm{b}}$ & $17.8 \pm 4.4^{\mathrm{b}}$ & $22.0 \pm 3.4^{\mathrm{b}}$ & $30.2 \pm 5.0^{\mathrm{a}}$ \\
& 4 & $31.0 \pm 2.9^{\mathrm{a}}$ & $33.0 \pm 2.7^{\mathrm{a}}$ & $20.0 \pm 4.0^{\mathrm{b}}$ & $19.0 \pm 2.6^{\mathrm{b}}$ & $\mathrm{N} / \mathrm{A}$ & $\mathrm{N} / \mathrm{A}$ \\
\hline b. Citric & & & & & & & \\
acid & 1 & $28.0 \pm 2.5^{\mathrm{b}}$ & $33.7 \pm 3.3^{\mathrm{a}}$ & $28.0 \pm 2.8^{\mathrm{b}}$ & $23.6 \pm 2.8^{\mathrm{c}}$ & $33.5 \pm 4.8^{\mathrm{a}}$ & $30.8 \pm 4.2^{\mathrm{a}}$ \\
& 2 & $45.0 \pm 3.0^{\mathrm{a}}$ & $44.2 \pm 3.8^{\mathrm{a}}$ & $25.0 \pm 3.1^{\mathrm{c}}$ & $28.7 \pm 3.2^{\mathrm{c}}$ & $41.0 \pm 3.7^{\mathrm{ab}} 33.4 \pm 4.4^{\mathrm{b}}$ \\
& 3 & $36.0 \pm 3.5^{\mathrm{a}}$ & $35.4 \pm 2.7^{\mathrm{a}}$ & $22.0 \pm 3.6^{\mathrm{c}}$ & $22.9 \pm 3.4^{\mathrm{c}}$ & $36.0 \pm 4.4^{\mathrm{a}}$ & $31.2 \pm 3.3^{\mathrm{b}}$ \\
& 4 & $41.5 \pm 2.0^{\mathrm{a}}$ & $37.4 \pm 1.9^{\mathrm{b}}$ & $22.0 \pm 3.2^{\mathrm{c}}$ & $23.6 \pm 3.6^{\mathrm{c}}$ & $\mathrm{N} / \mathrm{A}$ & $\mathrm{N} / \mathrm{A}$ \\
\hline c.Sodium & & & & & & & \\
benzoate & 1 & $35.0 \pm 1.9^{\mathrm{a}}$ & $33.5 \pm 2.2^{\mathrm{a}}$ & $26.0 \pm 3.4^{\mathrm{b}}$ & $23.0 \pm 3.9^{\mathrm{bc}}$ & $19.5 \pm 4.4 \mathrm{c}$ & $24.0 \pm 3.4^{\mathrm{b}}$ \\
& 2 & $41.0 \pm 2.3^{\mathrm{a}}$ & $44.3 \pm 2.7^{\mathrm{a}}$ & $27.0 \pm 2.1^{\mathrm{b}}$ & $25.8 \pm 4.2^{\mathrm{b}}$ & $25.5 \pm 4.2^{\mathrm{bc}}$ & $22.2 \pm 2.8^{\mathrm{cd}}$ \\
& 3 & $36.5 \pm 3.5^{\mathrm{a}}$ & $39.7 \pm 3.4^{\mathrm{a}}$ & $22.0 \pm 3.5^{\mathrm{c}}$ & $21.4 \pm 1.9^{\mathrm{c}}$ & $26.5 \pm 4.3^{\mathrm{b}}$ & $28.2 \pm 3.7^{\mathrm{b}}$ \\
& 4 & $46.0 \pm 3.1^{\mathrm{a}}$ & $48.7 \pm 3.1^{\mathrm{a}}$ & $24.0 \pm 2.8^{\mathrm{b}}$ & $22.3 \pm 4.0^{\mathrm{c}}$ & $\mathrm{N} / \mathrm{A}$ & $\mathrm{N} / \mathrm{A}$ \\
\hline \multicolumn{7}{l}{ Volues are means $\pm \mathrm{SD}(\mathrm{n}=3$ and $\mathrm{p}<0.05)}$, & Mean value within each
\end{tabular}
row followed by different letters differ significantly at $\mathrm{p}<0.05$

\subsubsection{Changes in the apparent color}


Results suggested that preservative types, container materials, and storage temperatures were strongly influenced on both lightness $\left(\mathrm{L}^{*}\right)$ and yellowness $\left(\mathrm{b}^{*}\right)$. After 4 weeks of storage, the bamboo shoot treated with citric acid exhibited the highest $L^{*}$ value (69.63) followed by the control sample (67.79) and the sample treated with sodium benzoate (66.27), respectively. In addition, considering the result of container materials on the lightness of products, the bamboo shoots treated with citric acid and the control sample in LDPE bags had higher lightness value than the fresh bamboo shoots stored in the laminate/nylon bags.

The bamboo shoots treated with citric acid in LDPE bags exhibited the highest $\mathrm{L}^{*}$ value (70.32), while the bamboo shoot treated with sodium benzoate in LDPE bags showed the lowest $L^{*}$ value (66.03). Changing storage temperatures strongly influenced on the $\mathrm{L}^{*}$ value of the products. Overall, the bamboo shoots stored at 4 ${ }^{\circ} \mathrm{C}$ showed the lowest $\mathrm{L}^{*}$ value in comparison with the products stored at -10 and $25{ }^{\circ} \mathrm{C}$. Sodium benzoatetreated bamboo shoot stored in LDPE at $25{ }^{\circ} \mathrm{C}$ had the highest $L^{*}$ value (72.44). The bamboo without preservatives in laminate/nylon bag at $-10{ }^{\circ} \mathrm{C}$ showed the lowest $L^{*}$ value (63.50) as Table 2 .

For the yellowness ) b* value( in Table 3, after 4 weeks of storage, sodium benzoate-treated bamboo shoot exhibited the lowest $b^{*}$ value )22.84( followed by the bamboo shoot treated with citric acid )23.54( and the bamboo shoot without addition of any preservatives )25.48(. For the container materials, the bamboo shoots stored in the LDPE bags had higher $b^{*}$ value than the bamboo shoot stored in the laminate/nylon bags. The bamboo shoot without preservatives in LDPE bags showed the highest $b^{*}$ value at 26.11 , while the bamboo shoot treated with citric acid in laminate/nylon exhibited the highest $b^{*}$ value at 22.10. Regarding the effect of storage temperatures, the bamboo shoot without any preservatives stored at $-10{ }^{\circ} \mathrm{C}$ had the highest $b^{*}$ value at 29.06, but the bamboo treated with citric acid in LPDE stored at $0-4{ }^{\circ} \mathrm{C}$ had the lowest $b^{*}$ value at 21.05 .

The statistical analysis )ANOVA( of $\mathrm{L}^{*}$ and $\mathrm{b}^{*}$ value indicated that major factors influenced the color changes $) \mathrm{L}^{*}$ and $\mathrm{b}^{*}($ were preservatives and storage temperatures at $95 \%$ confident intervals. However, the container types did not show significant influence on $\mathrm{L}^{*}$ value at $95 \%$ confident intervals. In addition, we also found that combined effects of 2 or 3 factors could influence on the color changes.

In addition to the extrinsic factors influencing the color changes as demonstrated in this report, other the intrinsic factors influencing on lipid peroxidation in plants are related three enzymes such as polyphenol oxidase ) $\mathrm{PPO}($, polyphenol peroxidase ) $\mathrm{POD}($ and phenylalanine ammonialyase )PAL(. These enzymes can cause enzymatic browning reaction under oxygen environment from polyphenolic compounds such as chlorogenic acid. PAL in the phenyl propanoid pathway also relates to the formation of cinnamic acid, coumaric acid and chlorogenic acid. Furthermore, it is well known that PPO can cause browning formation during harvesting and food processing. In the case of POD in fruits and vegetables can affect to oxidation of phenolic compounds via reduction of hydrogen peroxide to water [14]. Thus, in this study, the blanching process of the bamboo shoots for $10 \mathrm{~min}$ should be able to inactivate these mentioned enzymes. Moreover, application of citric acid or sodium benzoate could increase the acidity of the products causing partially inactivation of the enzymes. However, these enzymatic inactivation processes should be further investigated.

Table 2. Changes in lightness $\left(\mathrm{L}^{*}\right)$ of bamboo shoots with and without preservatives a. control; b. citric acid $(0.1 \% \mathrm{w} / \mathrm{v}) ; \mathrm{c}$. sodium benzoate $(1.0 \% \mathrm{w} / \mathrm{v})$ in different container materials and storage temperatures.

\begin{tabular}{lccccccc}
\hline Sample & $\begin{array}{c}\text { Storage } \\
\text { Time (week) }\end{array}$ & \multicolumn{2}{c}{$-10^{\circ} \mathrm{C}$} & \multicolumn{2}{c}{$4^{\circ} \mathrm{C}$} & \multicolumn{2}{c}{$25^{\circ} \mathrm{C}$} \\
\cline { 2 - 8 } & & LDPE & Laminate & LDPE & Laminate & LDPE & Laminate \\
\hline a.Control & 1 & $65.0 \pm 3.7$ & $66.0 \pm 4.3$ & $66.0 \pm 6.9$ & $65.0 \pm 3.8$ & $68.0 \pm 5.0$ & $68.0 \pm 3.9$ \\
& 2 & $68.0 \pm 3.7^{\mathrm{ab}}$ & $70.0 \pm 4.8^{\mathrm{a}}$ & $65.0 \pm 4.1^{\mathrm{b}}$ & $67.0 \pm 5.7^{\mathrm{ab}}$ & $72.0 \pm 3.6^{\mathrm{a}}$ & $72.0 \pm 3.6^{\mathrm{a}}$ \\
& 3 & $66.0 \pm 4.6^{\mathrm{b}}$ & $70.5 \pm 4.4^{\mathrm{ab}}$ & $67.0 \pm 4.1^{\mathrm{b}}$ & $67.5 \pm 5.1^{\mathrm{b}}$ & $75.0 \pm 5.2^{\mathrm{a}}$ & $75.0 \pm 4.7^{\mathrm{a}}$ \\
& 4 & $69.0 \pm 3.7^{\mathrm{ab}}$ & $72.0 \pm 4.5^{\mathrm{a}}$ & $65.0 \pm 3.5^{\mathrm{b}}$ & $71.0 \pm 5.3^{\mathrm{a}}$ & $\mathrm{N} / \mathrm{A}$ & $\mathrm{N} / \mathrm{A}$ \\
\hline b.Citric & & & & & & & \\
acid & 1 & $71.0 \pm 4.4$ & $71.0 \pm 6.5$ & $70.0 \pm 5.7$ & $72.0 \pm 5.2$ & $71.8 \pm 5.8$ & $72.8 \pm 4.2$ \\
& 2 & $72.0 \pm 4.5^{\mathrm{ab}}$ & $71.1 \pm 6.6^{\mathrm{b}}$ & $73.0 \pm 6.5^{\mathrm{a}}$ & $73.0 \pm 5.2^{\mathrm{a}}$ & $73.0 \pm 5.5^{\mathrm{a}}$ & $74.0 \pm 6.1^{\mathrm{a}}$ \\
& 3 & $74.0 \pm 5.9^{\mathrm{a}}$ & $73.0 \pm 4.9^{\mathrm{ab}}$ & $74.0 \pm 4.3^{\mathrm{a}}$ & $72.9 \pm 3.7^{\mathrm{ab}}$ & $75.0 \pm 5.1^{\mathrm{a}}$ & $76.0 \pm 4.6^{\mathrm{a}}$ \\
& 4 & $75.0 \pm 6.2$ & $74.1 \pm 3.4$ & $73.0 \pm 4.0$ & $74.0 \pm 3.9$ & $\mathrm{~N} / \mathrm{A}$ & $\mathrm{N} / \mathrm{A}$ \\
\hline c.Sodium & & & & & & & \\
benzoate & 1 & $63.0 \pm 5.8$ & $62.0 \pm 3.9$ & $65.0 \pm 4.3$ & $64.0 \pm 3.4$ & $64.0 \pm 4.7$ & $67.0 \pm 4.3$ \\
& 2 & $64.0 \pm 4.7^{\mathrm{b}}$ & $62.8 \pm 3.1^{\mathrm{b}}$ & $68.0 \pm 4.5^{\mathrm{a}}$ & $69.7 \pm 5.2^{\mathrm{a}}$ & $67.0 \pm 5.1^{\mathrm{ab}}$ & $71.0 \pm 2.7^{\mathrm{a}}$ \\
& 3 & $66.4 \pm 3.8^{\mathrm{ab}}$ & $65.0 \pm 3.9^{\mathrm{b}}$ & $67.0 \pm 4.3^{\mathrm{a}}$ & $69.0 \pm 4.5^{\mathrm{a}}$ & $71.0 \pm 2.6^{\mathrm{a}}$ & $72.0 \pm 5.5^{\mathrm{a}}$ \\
& 4 & $66.5 \pm 3.5^{\text {ab }}$ & $64.4 \pm 4.4^{\mathrm{b}}$ & $70.0 \pm 3.7^{\mathrm{a}}$ & $71.6 \pm 3.9^{\mathrm{a}}$ & $\mathrm{N} / \mathrm{A}$ & $\mathrm{N} / \mathrm{A}$ \\
\hline
\end{tabular}

Volues are means \pm SD $(n=3$ and $p<0.05)$, Mean value within each row followed by different letters differ significantly at $\mathrm{p}<0.05$

Table 3. Changes in yellowness $\left(b^{*}\right)$ of bamboo shoots with and without preservatives a. control; $b$. citric acid $(0.1 \% \mathrm{w} / \mathrm{v})$; c. sodium benzoate $(1.0 \% \mathrm{w} / \mathrm{v})$ in different container materials and storage temperatures.

\begin{tabular}{lccccccc}
\hline Sample & Storage & \multicolumn{2}{c}{$-10^{\circ} \mathrm{C}$} & \multicolumn{2}{c}{$4^{\circ} \mathrm{C}$} & \multicolumn{2}{c}{$25^{\circ} \mathrm{C}$} \\
\cline { 3 - 8 } & Time (week) & LDPE & Laminate & LDPE & Laminate & LDPE & Laminate \\
\hline a.Control & 1 & $21.0 \pm 2.6$ & $21.4 \pm 3.3$ & $20.0 \pm 1.9$ & $21.0 \pm 3.8$ & $20.0 \pm 2.0$ & $20.7 \pm 1.9$ \\
& 2 & $23.0 \pm 2.7^{\mathrm{b}}$ & $27.1 \pm 2.8^{\mathrm{a}}$ & $23.6 \pm 2.1^{\mathrm{b}}$ & $23.1 \pm 1.7^{\mathrm{b}}$ & $23.8 \pm 3.6^{\mathrm{b}}$ & $24.6 \pm 1.6^{\mathrm{ab}}$ \\
& 3 & $22.4 \pm 2.6^{\mathrm{b}}$ & $26.8 \pm 2.4^{\mathrm{a}}$ & $23.0 \pm 2.1^{\mathrm{b}}$ & $22.7 \pm 3.1^{\mathrm{b}}$ & $25.0 \pm 2.2^{\mathrm{ab}}$ & $26.0 \pm 1.7^{\mathrm{a}}$ \\
& 4 & $23.4 \pm 2.5^{\mathrm{b}}$ & $28.8 \pm 2.5^{\mathrm{a}}$ & $23.2 \pm 3.5^{\mathrm{b}}$ & $20.8 \pm 2.3^{\mathrm{b}}$ & $\mathrm{N} / \mathrm{A}$ & $\mathrm{N} / \mathrm{A}$ \\
\hline b.Citric $^{\text {acid }}$ & & & & & & & \\
& 1 & $20.0 \pm 2.4$ & $20.7 \pm 2.5$ & $20.0 \pm 3.7$ & $21.0 \pm 2.2$ & $21.5 \pm 1.8$ & $21.6 \pm 2.5$ \\
& 2 & $22.5 \pm 3.5$ & $20.1 \pm 3.6$ & $20.5 \pm 1.5$ & $22.3 \pm 2.2$ & $22.7 \pm 2.5$ & $22.3 \pm 2.2$ \\
& 3 & $21.4 \pm 1.9$ & $21.0 \pm 2.9$ & $20.4 \pm 2.3$ & $21.5 \pm 1.7$ & $23.0 \pm 3.1$ & $22.0 \pm 2.8$ \\
& 4 & $21.6 \pm 2.2$ & $22.2 \pm 3.2$ & $19.5 \pm 2.4$ & $21.1 \pm 3.2$ & $\mathrm{~N} / \mathrm{A}$ & $\mathrm{N} / \mathrm{A}$ \\
\hline c.Sodium $^{\text {benzoate }}$ & 1 & $21.0 \pm 2.8$ & $21.4 \pm 2.9$ & $20.0 \pm 2.3$ & $21.0 \pm 1.9$ & $20.0 \pm 1.7$ & $20.7 \pm 2.3$ \\
& 2 & $21.4 \pm 2.7$ & $21.9 \pm 2.8$ & $22.4 \pm 2.5$ & $21.2 \pm 3.2$ & $22.1 \pm 3.1$ & $21.0 \pm 1.7$ \\
& 3 & $22.0 \pm 2.8$ & $22.0 \pm 3.4$ & $22.8 \pm 2.3$ & $20.7 \pm 2.4$ & $22.0 \pm 2.6$ & $22.4 \pm 2.5$ \\
& 4 & $23.8 \pm 3.5$ & $22.4 \pm 2.1$ & $23.7 \pm 3.1$ & $21.3 \pm 1.8$ & N/A & N/A \\
\hline
\end{tabular}

Volues are means $\pm \mathrm{SD}(\mathrm{n}=3$ and $\mathrm{p}<0.05)$, Mean value within each row followed by different letters differ significantly at $\mathrm{p}<0.05$

\subsection{Changes in microorganisms}

Changes in total plate count (TPC) and total coliform bacteria of the bamboo shoots during 4 weeks of storage were investigated. Results showed that the bamboo shoot treated with citric acid had the longest shelf life in terms of microbial stability as indicated by the lowest TPC and total coliform bacteria followed by the bamboo shoots 
without any preservatives (control) and the treatment with sodium benzoate. After stored for 4 weeks, TPC value and coliform bacteria of the bamboo shoot kept at $10{ }^{\circ} \mathrm{C}$ in the LDPE bags were $54 \mathrm{CFU} / \mathrm{g}$ and $<3 \mathrm{MPN} / \mathrm{g}$, respectively. In case of the control sample, TPC value and coliform bacteria were $80 \mathrm{CFU} / \mathrm{g}$ and $<3 \mathrm{MPN} / \mathrm{g}$, respectively. In addition, in case of the bamboo shoots treated with sodium benzoate, TPC value and coliform bacteria were $1.4 \times 10^{3} \mathrm{CFU} / \mathrm{g}$ and $9.2 \mathrm{MPN} / \mathrm{g}$, respectively (Table 4). This was showed a higher storage temperature affected to a higher microorganism in the bamboo shoot. Therefore, the deterioration of physical characteristic was obviously observed such as fermentation or spoilage smells and unacceptable soft texture. It was found that the bamboo shoots treated with citric acid and the control sample stored at $4^{\circ} \mathrm{C}$ in LDPE and laminate/nylon bags had longer shelf life based on texture properties $(<4$ weeks) than the bamboo shoot treated with sodium benzoate $(<2$ weeks) (Table 4 , Table 5). The same was true for the bamboo shoot kept at 25 ${ }^{\circ} \mathrm{C}$. In general, sodium benzoate exhibited poor antimicrobial property since the bamboo shoot treated with sodium benzoate could be stored less than 2 weeks.

For the effect of storage temperature, it was clear that the lower temperature, the lower microbial growth was observed. The bamboo shoots stored at $-10{ }^{\circ} \mathrm{C}$ exhibited the highest microbial stability in comparison with other temperatures. After 2 weeks of storage, total microbial plate counts of the products stored at $-10,4$ and $25{ }^{\circ} \mathrm{C}$ were $<10$ )none(, $1.9 \times 10^{3}$ and $1.2 \times 10^{6}$ $\mathrm{CFU} / \mathrm{g}$, respectively. Nevertheless, with different container materials, it was found that the container materials did not show significant differences on microbial growth during 4 weeks of storage. Badwaik et al. )2014( reported that the surface microbial in bamboo shoot was increased from 4.60 to $6.20 \log \mathrm{CFU} / \mathrm{cm}^{2}$ during 5days storage at room temperature $) 30 \pm 2^{\circ} \mathrm{C}$ ( and relative humidity of $64 \pm 3 \%$.

In general, total plate and coliform bacteria counts are used as the indicator for shelf life estimation. These plate count techniques determine the number of aerobic bacteria at normal temperature, at which they are not specific to types of bacteria. Environmental factors such as temperature, acidity, and oxygen content can influence on the growth of microorganisms. Moreover, coliform bacteria count is used as a sanitation indicator that could be contaminated from hands, containers, soil, air, and water during processes into food products, since coliform bacteria are commonly found in the digestive tracts of animals. However, coliform bacteria can be easily destroyed by heating at $60-70{ }^{\circ} \mathrm{C}$.

Besides the storage temperature, the acidity of the bamboo shoots was also important parameters In this study, two types of acidify agents )citric acid and sodium benzoate( were used to lower the $\mathrm{pH}$ value of products. Both acidify agents could decrease the $\mathrm{pH}$ value of the bamboo shoots to $3.27 \pm 0.15$ for citric acid and sodium benzoate. However, sodium benzoate can decrease the $\mathrm{pH}$ value of product to $5.53 \pm 0.38$. In general, at the $\mathrm{pH}$ lower than 4.5, most anaerobic pathogenic bacteria such as Clostridium sp.are effectively inhibited. Products treated with sodium benzoate may carry a high risk of causing food poisoning from thermophilic and mesophilic flat-sour organisms, and thermophilic anaerobes. Thus, it was necessary to determine these microorganisms for a human risk assessment from consumption of bamboo shoots.

Table 4. Total Plate Count (cfu/g) and Coliform bacteria (MPN/g) in bamboo shoot under LDPE packaging during storage for 4 weeks at different temperature.

\begin{tabular}{|c|c|c|c|c|c|c|c|}
\hline \multirow[t]{2}{*}{ Sample } & \multirow{2}{*}{$\begin{array}{c}\text { Storage } \\
\text { Time (week) }\end{array}$} & \multicolumn{2}{|c|}{$-10^{\circ} \mathrm{C}$} & \multicolumn{2}{|c|}{$4^{\circ} \mathrm{C}$} & \multicolumn{2}{|c|}{$25^{\circ} \mathrm{C}$} \\
\hline & & TPC & coliform & TPC & coliform & TPC & coliform \\
\hline \multirow[t]{4}{*}{ Control } & 1 & $<10$ & $<3$ & $1.2 \times 10^{2}$ & $<3$ & $3.2 \times 10^{2}$ & $<3$ \\
\hline & 2 & $<10$ & $<3$ & $1.9 \times 10^{3}$ & $<3$ & $1.2 \times 10^{6}$ & $<3$ \\
\hline & 3 & $1.0 \times 10^{2}$ & $<3$ & $5.4 \times 10^{7}$ & 23 & N/A & N/A \\
\hline & 4 & 80 & $<3$ & N/A & N/A & N/A & N/A \\
\hline \multirow[t]{4}{*}{$\begin{array}{l}\text { Citric } \\
\text { acid }\end{array}$} & 1 & $<10$ & $<3$ & $<10$ & $<3$ & 90 & $<3$ \\
\hline & 2 & $<10$ & $<3$ & $1.1 \times 10^{2}$ & $<3$ & $3.4 \times 10^{5}$ & $<3$ \\
\hline & 3 & 35 & $<3$ & $3.4 \times 10^{7}$ & 460 & N/A & N/A \\
\hline & 4 & 54 & $<3$ & N/A & N/A & N/A & N/A \\
\hline \multirow[t]{4}{*}{$\begin{array}{l}\text { Sodium } \\
\text { benzoate }\end{array}$} & 1 & $<10$ & $<3$ & $1.2 \times 10^{3}$ & 9.2 & $3.6 \times 10^{6}$ & 460 \\
\hline & 2 & $<10$ & $<3$ & $1.3 \times 10^{7}$ & 240 & N/A & N/A \\
\hline & 3 & $1.0 \times 10^{2}$ & $<3$ & N/A & N/A & $\mathrm{N} / \mathrm{A}$ & N/A \\
\hline & 4 & $1.4 \times 10^{3}$ & 9.2 & N/A & N/A & N/A & N/A \\
\hline
\end{tabular}

Table 5. Total Plate Count (cfu/g) and Coliform bacteria (MPN/g) in bamboo shoot under laminate /nylon packaging during storage for 4 weeks at different temperature.

\begin{tabular}{lccccccc}
\hline Sample & Storage & \multicolumn{2}{c}{$-10^{\circ} \mathrm{C}$} & \multicolumn{2}{c}{$4{ }^{\circ} \mathrm{C}$} & \multicolumn{2}{c}{$25^{\circ} \mathrm{C}$} \\
\cline { 3 - 8 } & Time (week) & TPC & coliform & TPC & coliform & TPC & coliform \\
\hline Control & 1 & $<10$ & $<3$ & 45 & $<3$ & $1.2 \times 10^{3}$ & $<3$ \\
& 2 & $<10$ & $<3$ & $1.7 \times 10^{2}$ & $<3$ & $4.5 \times 10^{4}$ & $<3$ \\
& 3 & $3.0 \times 10^{2}$ & $<3$ & $5.4 \times 10^{7}$ & 9.2 & N/A & N/A \\
& 4 & $1.2 \times 10^{2}$ & $<3$ & N/A & N/A & N/A & N/A \\
\hline Citric & & & & & & & \\
acid & 1 & $<10$ & $<3$ & 85 & $<3$ & $3.1 \times 10^{4}$ & $<3$ \\
& 2 & $<10$ & $<3$ & $<10$ & $<3$ & $2.0 \times 10^{7}$ & $<3$ \\
& 3 & $<10$ & $<3$ & $1.5 \times 10^{7}$ & $<3$ & N/A & N/A \\
& 4 & 20 & $<3$ & N/A & N/A & N/A & N/A \\
\hline Sodium & & $<10$ & $<3$ & $3.4 \times 10^{3}$ & 460 & $1.1 \times 10^{7}$ & 460 \\
benzoate & 1 & $<10$ & $<3$ & $1.3 \times 10^{6}$ & 240 & N/A & N/A \\
& 2 & $<10$ & $<3$ & N/A & N/A & N/A & N/A \\
& 3 & $1.4 \times 10^{3}$ & 9.2 & N/A & N/A & N/A & N/A \\
\hline
\end{tabular}

Volues are means $\pm \mathrm{SD}(\mathrm{n}=3$ and $\mathrm{p}<0.05)$

\subsection{Changes in sensory qualities}

Preference test in terms of odor, color, and overall likeness of bamboo shoots during 1 to 4 weeks of storage was evaluated (Table 6, Table 7). Results showed that for the bamboo shoots stored at $4^{\circ} \mathrm{C}$ for 4 weeks, the odor and color liking scores of the control sample and the citric acid-treated bamboo shoot obtained were approximately 4 to 5 (between neither like nor dislike and like moderately). However, these linking scores were lower in the sodium benzoate-treated bamboo shoot, which were around 2 to 3 (between dislike moderately and dislike very much). Overall, the obtained color linking score of the products was higher than the obtained odor linking score. It was found that some bamboo shoots were spoiled, so they could not be 
performed sensory evaluation. For instance, the sodium benzoate-treated bamboo shoots stored at $25^{\circ} \mathrm{C}$ in both container materials had spoiled at 2 weeks of storage. In addition, after 4 weeks of storage at 4 and $25{ }^{\circ} \mathrm{C}$, all bamboo shoot samples had spoiled. Only the bamboo shoot samples stored at $-10{ }^{\circ} \mathrm{C}$ could be stored up to 4 weeks without noticeable microbial spoilage.

Table 6. Sensory evaluation of bamboo shoot under LDPE packaging during 4 weeks storage at different temperatures.

\begin{tabular}{|c|c|c|c|c|c|c|c|}
\hline \multirow[t]{2}{*}{ Sample } & \multirow{2}{*}{$\begin{array}{l}\text { Storage } \\
\text { Time (week) }\end{array}$} & \multicolumn{2}{|c|}{$-10^{\circ} \mathrm{C}$} & \multicolumn{2}{|c|}{$4^{\circ} \mathrm{C}$} & \multicolumn{2}{|c|}{$25^{\circ} \mathrm{C}$} \\
\hline & & Flavor & Color & Flavor & Color & Flavor & Color \\
\hline \multirow[t]{4}{*}{$\overline{\text { Control }}$} & 1 & $5.33 \pm 0.52$ & $4.83 \pm 0.75$ & $6.33 \pm 0.58$ & $5.50 \pm 0.85$ & $4.33 \pm 0.53$ & $4.33 \pm 0.78$ \\
\hline & 2 & $5.21 \pm 1.07$ & $4.13 \pm 1.02$ & $5.03 \pm 0.83$ & $5.06 \pm 0.72$ & $2.63 \pm 0.91$ & $2.14 \pm 1.17$ \\
\hline & 3 & $5.00 \pm 1.32$ & $4.22 \pm 0.64$ & $4.89 \pm 1.03$ & $4.78 \pm 0.67$ & N/A & N/A \\
\hline & 4 & $4.17 \pm 1.14$ & $4.06 \pm 0.73$ & $4.18 \pm 0.73$ & $4.01 \pm 1.06$ & N/A & N/A \\
\hline \multirow[t]{4}{*}{$\begin{array}{l}\text { Citric } \\
\text { acid }\end{array}$} & 1 & $4.67 \pm 1.02$ & $4.67 \pm 0.57$ & $4.17 \pm 0.41$ & $4.67 \pm 0.93$ & $4.00 \pm 0.63$ & $3.17 \pm 0.41$ \\
\hline & 2 & $3.92 \pm 1.31$ & $2.89 \pm 0.94$ & $3.72 \pm 1.05$ & $3.16 \pm 0.78$ & $2.82 \pm 0.95$ & $2.42 \pm 0.78$ \\
\hline & 3 & $3.17 \pm 1.06$ & $3.04 \pm 0.93$ & $3.11 \pm 1.12$ & $3.89 \pm 0.83$ & N/A & N/A \\
\hline & 4 & $3.76 \pm 1.14$ & $3.09 \pm 1.09$ & $3.73 \pm 1.05$ & $3.92 \pm 0.91$ & N/A & N/A \\
\hline \multirow[t]{4}{*}{$\begin{array}{l}\text { Sodium } \\
\text { benzoate }\end{array}$} & 1 & $5.00 \pm 1.06$ & $4.17 \pm 0.82$ & $4.33 \pm 0.52$ & $3.33 \pm 0.92$ & $3.67 \pm 0.72$ & $2.17 \pm 0.41$ \\
\hline & 2 & $3.17 \pm 0.74$ & $3.07 \pm 0.74$ & $2.72 \pm 0.48$ & $3.33 \pm 0.52$ & N/A & N/A \\
\hline & 3 & $2.89 \pm 1.45$ & $2.56 \pm 0.88$ & $3.06 \pm 0.73$ & $3.02 \pm 0.67$ & N/A & N/A \\
\hline & 4 & $2.74 \pm 1.06$ & $2.94 \pm 0.97$ & N/A & N/A & N/A & N/A \\
\hline
\end{tabular}

Table 7. Sensory evaluation of bamboo shoot laminate /nylon packaging during 4 weeks storage at different temperatures.

\begin{tabular}{|c|c|c|c|c|c|c|c|}
\hline \multirow[t]{2}{*}{ Sample } & \multirow{2}{*}{$\begin{array}{l}\text { Storage } \\
\text { Time (week) }\end{array}$} & \multicolumn{2}{|c|}{$-10^{\circ} \mathrm{C}$} & \multicolumn{2}{|c|}{$4^{\circ} \mathrm{C}$} & \multicolumn{2}{|c|}{$25^{\circ} \mathrm{C}$} \\
\hline & & Flavor & Color & Flavor & Color & Flavor & Color \\
\hline \multirow[t]{4}{*}{ Control } & 1 & $5.83 \pm 0.78$ & $5.50 \pm 0.57$ & $6.13 \pm 0.55$ & $5.17 \pm 0.41$ & $4.83 \pm 0.98$ & $4.00 \pm 0.63$ \\
\hline & 2 & $4.83 \pm 0.82$ & $4.33 \pm 1.02$ & $4.36 \pm 1.09$ & $4.41 \pm 1.32$ & $3.78 \pm 0.55$ & $3.23 \pm 1.14$ \\
\hline & 3 & $4.17 \pm 0.84$ & $4.07 \pm 0.87$ & $4.47 \pm 0.41$ & $4.17 \pm 0.52$ & N/A & N/A \\
\hline & 4 & $4.06 \pm 0.92$ & $4.14 \pm 0.91$ & $3.91 \pm 0.67$ & $4.02 \pm 0.57$ & N/A & N/A \\
\hline \multirow[t]{4}{*}{$\begin{array}{l}\text { Citric } \\
\text { acid }\end{array}$} & 1 & $4.17 \pm 0.41$ & $4.83 \pm 0.72$ & $5.33 \pm 0.52$ & $5.17 \pm 0.41$ & $4.50 \pm 1.05$ & $4.17 \pm 0.41$ \\
\hline & 2 & $4.33 \pm 0.71$ & $4.11 \pm 0.52$ & $4.02 \pm 0.94$ & $4.22 \pm 0.67$ & $2.73 \pm 0.59$ & $2.78 \pm 0.67$ \\
\hline & 3 & $4.42 \pm 0.57$ & $4.23 \pm 1.04$ & $3.89 \pm 0.78$ & $3.04 \pm 1.04$ & N/A & N/A \\
\hline & 4 & $4.33 \pm 0.95$ & $4.78 \pm 1.20$ & $3.92 \pm 0.83$ & $3.36 \pm 0.95$ & N/A & $\mathrm{N} / \mathrm{A}$ \\
\hline \multirow[t]{4}{*}{$\begin{array}{l}\text { Sodium } \\
\text { benzoate }\end{array}$} & 1 & $4.67 \pm 0.82$ & $4.33 \pm 0.82$ & $4.17 \pm 0.64$ & $4.17 \pm 0.48$ & $4.50 \pm 0.55$ & $5.00 \pm 1.41$ \\
\hline & 2 & $3.97 \pm 0.91$ & $3.72 \pm 0.97$ & $4.02 \pm 0.59$ & $3.74 \pm 0.48$ & $\mathrm{~N} / \mathrm{A}$ & $\mathrm{N} / \mathrm{A}$ \\
\hline & 3 & $3.10 \pm 0.53$ & $3.02 \pm 0.46$ & $3.27 \pm 1.07$ & $3.00 \pm 0.87$ & N/A & N/A \\
\hline & 4 & $2.83 \pm 0.82$ & $2.11 \pm 1.04$ & N/A & N/A & N/A & $\mathrm{N} / \mathrm{A}$ \\
\hline
\end{tabular}

Volues are means \pm SD $(n=3$ and $p<0.05)$

\section{Conclusions}

Overall quality of ready-to-eat trimmed and sliced phaitong bamboo shoot products is strongly influenced by container, storage temperature and preservatives. Sodium benzoate could prevent discoloration of bamboo shoot products; however, the bamboo shoot had shorter shelf life in terms of microbial stability in comparison with other preservatives. Controlling storage temperatures had dramatically influenced on all tested parameters including weight loss, discoloration, shelf life, and sensory quality. In general, the bamboo products tested for long-term storage (4 weeks) at lower temperature had higher qualities in terms of sensory quality, color, and microbial stability than the product stored at higher temperature. Optimum storage temperature was around at $4{ }^{\circ} \mathrm{C}$ since the bamboo shoot product had the lowest weight loss; however, increases in the storage temperature beyond this point, the weight loss of the product also increased. Using improved bamboo processing and optimal packaging contributes to the fresh bamboo shoot quality which is safe and prolong shelf stable until consumption. The fresh cut bamboo shoots market for perspective consumers who expect exotic flavor is very special and large market. Therefore, effective marketing strategies need to be created to reach both customers domestically and internationally. Fresh cut bamboo shoots with advance technology (High Pressure) are further studies on the satety and nutritional value. It should be an opportunity for product to make consumers confident in their consumption.

\section{References}

1. F. Zeng, Z. Luo, J. Xie, S. Feng, Gamma radiation control quality and lignification of bamboo shoots )Phyllostachys praecox f. prevernalis. ( stored at low temperature, Postharvest Biology and Technology, 102 (2015): 17-24

2. R. Pattanavibool, Bamboo research and development in Thailand (2000) in BambooConservation, Diversity, Ecogeography, Germplasm, Resource Utilization and Taxonomy. https://www.bioversityinternational.org/fileadmin/bi oversity/publications/Web_version/572/ch32.htm [available online 29 April, 2021]

3. V. Kleinhenz, M. Gosbee, T.W. Lyall, K. Blackburn, K. Harrower, D.J. Midmore, Storage methods for extending shelf life of fresh, edible bamboo shoots ]Bambusa oldhamii )Munro([, Postharvest Biology and Technology, 19 (2000): 253-264

4. Prachinburi Provincial Agriculture Office, Statistical of gross domestic product of Prachinburi province, 2554/2555. ]Available on http://klang.cgd.go.th/pri/menu3.html. )June, 2015([

5. C. Techapun, Feasibility study on establishment of bamboo shoot products plant in Chiang Mai, Royal Forest Department, International Tropical Timber Organization, Bangkok, (2004): 46

6. K. Chiangthong, L. Chayawat, Bamboo shoot stream processing from Tha Sao community, Sai Yoke district, Kanchanaburi Province. Kanchanaburi 71000: Department of Science and Technology, Kanchanaburi Rajabhat University, Thailand. www.brt. biotec.or.th/upload/Eng\%208bambo.doc. (2009)

7. P.Nongdam and L. Tikendra, The nutritional facts of bamboo shoots and their usage as important traditional foods of northeast india, Interanational scholarly research notices, (2014): 17

8. A.K. Pandey,V. Ojha, S.K. Choubey, Development and shelf-life evaluation of value added edible products from bamboo shoots, American Journal of Food Technology, 7 (2012): 363-371 
9. J. Tipmontian, R.K. Suryaprasa, M. Rajmohan, P. Limpapawich, Assessment and selection of postharvest treatment in a fresh bamboo shoot supply chain", $15^{\text {th }}$ Food Innovation Asia Conference 2013, June 2013, Bangkok, Thailand

10. B.P. Bhatt, L.B. Singha, K. Singh, M.S. Sachan, Some commercial edible bamboo species of North East India: production, indigenous uses, cost-benefit and management strategies, The Journal of the American Bamboo Society, 17, 1 (2003(: 4-20

11. Y. Qing, B.D. Zhu, L.W. Zheng, H.H. Kai, X.S. Qi, H.P. Zhen, Bamboo resources, utilization and exsitu conservation in Xishuangbanna, South-eastern China, Journal of Forestry Research, 19, 1 )2008(: 79-83

12. Y. Xu, M. Zhang, D. Tu, J. Sun, L. Zhou, A.S. Mujumdar, A two-stage convective air and vacuum freeze drying technique for bamboo shoots, International Journal of Food Science and Technology, 40, 6 (2005): 589-595

13. T. Wongsakpaiod, Bamboo shoot drying using superheated steam [Meng. Thesis] Bangkok, Thailand: King Mongkut's University of Technology (2000)

14. Q. Shen, F. Kong, Q. Wang, Effect of modified atmosphere packaging on the browning and lignification of bamboo shoots, Journal of Food Engineering, 77 (2006): 348-354

15. Z. Luo, S. Feng, J. Pang, M. Mao, H. Shou, J. Xie, Effect of heat treatment on lignification of postharvest bamboo shoots )Phyllostachys praecox f. prevernalis(, Food Chemistry, 135 (2012a): 21822187

16. H. Yang, C. Zhou, F. Wu, J. Cheng, Effect of nitric oxide on browning and lignification of peeled bamboo shoots, Postharvest Biology and Technology, 57 (2010): 72-76

17. Z. Luo, X. Wu, Y. Xie, C. Chen, Alleviation of chilling injury and browning of postharvest bamboo shoot by salicylic acid treatment. Food Chemistry, 131 (2012b): 456-461

18. Z. Luo, X. Xu, Z. Cai, B. Yan, Effects of ethylene and 1-methylcyclopropene )1-MCP( on lignification of postharvest bamboo shoots, Food Chemistry, 105 (2007) : 521-527

19. L.S. Badwaik, P.K. Borah, S.C. Deka, Antimicrobial and enzymatic antibrowning film used as coating for bamboo shoot quality improvement, Carbohydrate Polymers, 103 (2014): 213-220

20. H.T. Lawless, H. Heymann, Sensory Evaluation of Food: Principles and Practices, Aspen Publishers, Inc., New York (1999) 